\title{
Insulin-like Growth Factor Binding Proteins from Cultured Human Fibroblasts Characterization and Hormonal Regulation
}

\author{
C. A. Conover, F. Liu, D. Powell, R. G. Rosenfeld, and R. L. Hintz \\ Department of Pediatrics, Stanford University, Stanford, California 94305
}

\begin{abstract}
Specific, high affinity insulin-like growth factor (IGF) binding proteins are secreted by human fibroblasts in culture. By multiple criteria, the species of IGF binding proteins produced by human fibroblasts are distinct from the HepG2/amniotic fluid IGF binding protein, but share many characteristics with the growth hormone-dependent IGF binding protein forms predominant in normal adult human plasma. Treatment of cultured human fibroblasts with growth hormone produced an increase in IGF binding protein activity in the medium, while addition of glucocorticoids markedly diminished IGF binding activity. Insulin, epidermal growth factor, platelet-derived growth factor, and progesterone had no effect on IGF binding activity in fibroblast media. In comparison, HepG2 IGF binding activity was enhanced by progesterone, decreased by insulin, and unaffected by growth hormone or glucocorticoid treatment. Five molecular forms of IGF binding proteins were identified by Western ligand blots in human fibroblast conditioned medium, with $M_{r}=41,500,37,000,32,000,28,000$, and 23,000. In human fibroblast conditioned medium, the $M_{\mathrm{r}}$ $=41,500$ and 37,000 IGF binding protein species were abundant, as in normal human plasma, with a major $M_{r}=23,000$ form which was a minor component in plasma.
\end{abstract}

\section{Introduction}

The insulin-like growth factors I and II (IGF-I and IGF-II) ${ }^{1}$ mediate many of growth hormone's anabolic effects in vivo, and have been shown to be important growth factors for a variety of cells in vitro, including human fibroblasts $(1,2)$. IGF-I and -II are carried as two major forms in human plasma, with relative molecular masses of $\sim 150,000$ and 40,000 (3). The $M_{\mathrm{r}}=150,000$ binding protein appears to be under growth hormone control and is the major carrier of IGF-I and IGF-II in the circulation. Evidence suggests that this big binding protein complex may be composed of smaller binding protein molecules (3-5). The small IGF binding protein is a minor form in normal adult plasma, but has been found to be elevated in fetal and growth hormone-deficient plasma. In addi-

\section{Address reprint requests to Dr. Conover, Mayo Clinic, Endocrine Re- search Unit, Room 5-164 West Joseph, Rochester, MN 55905. \\ Received for publication 7 September 1988 and in revised form 17 October 1988.}

1. Abbreviations used in this paper: EGF, epidermal growth factor; IGF-I and -II, insulin-like growth factor I and II; PDGF, platelet-derived growth factor.

J. Clin. Invest.

(C) The American Society for Clinical Investigation, Inc.

$0021-9738 / 89 / 03 / 0852 / 08 \quad \$ 2.00$

Volume 83, March 1989, 852-859 tion, a variety of human cells and biological fluids have been shown to produce or contain IGF-specific binding proteins. $M_{\mathrm{r}}$ $=28,000$ IGF binding proteins have been purified from human amniotic fluid (6) and from culture medium conditioned by a human hepatoma line, HepG2 (7), which by immunological and sequence data have been shown to be similar or identical proteins (8). IGF binding activity has also been detected in the conditioned medium of cultured human skin fibroblasts (9), and has been suggested to modulate IGF action (10). Although there has been implied identity of low molecular weight human fibroblast IGF binding protein to the HepG2/amniotic fluid IGF binding protein (11), its structural characterization and relationship to various binding proteins in human plasma and other fluids have not been established. Furthermore, the hormonal regulation and physiological significance of these different IGF binding protein species are unknown.

This study describes the characterization and regulation of the IGF binding protein species secreted by cultured human skin fibroblasts.

\section{Methods}

Materials. Recombinant DNA-derived $\mathrm{Thr}^{59}$-IGF-I was purchased from Amgen Biological Corp. (Thousand Oaks, CA). Synthetic IGF-II was provided by Dr. C. H. Li (San Francisco, CA). Epidermal growth factor (EGF) and platelet derived growth factor (PDGF) were obtained from Collaborative Research, Inc. (Lexington, MA). Recombinant human growth hormone was supplied by Genentech, Inc. (South San Francisco, CA), and crystalline human insulin was from Eli Lilly \& Co. (Indianapolis, IN). Dexamethasone, hydrocortisone, beta-estradiol, progesterone, testosterone, protamine sulfate, activated charcoal, and BSA were purchased from Sigma Chemical Co. (St. Louis, MO). Con A was from Pharmacia Fine Chemicals (Uppsala, Sweden). Prestained molecular weight protein standards and RNA ladder were obtained from Bethesda Research Laboratories (Gaithersburg, MD). IGFs were iodinated by a modification of the chloramine $T$ method $(12,13)$ to a specific activity of $150-300 \mu \mathrm{Ci} / \mu \mathrm{g}$.

Cell cultures. Normal human fibroblasts of dermal origin were purchased from the Human Genetic Mutant Cell Repository (Camden, NJ) and the American Type Culture Collection (Rockville, MD). Fibroblasts were cultured in DME (Irvine Scientific Co., Santa Ana, CA) supplemented with $100 \mathrm{U} / \mathrm{ml}$ penicillin, $100 \mu \mathrm{g} / \mathrm{ml}$ streptomycin, and $4 \mathrm{mM}$ glutamine, and containing $10 \%$ supplemented calf serum (HyClone Laboratories, Logan, UT), as previously described (2).

HepG2 cells, originally isolated from a human hepatoma, were kindly provided by Dr. A. D. Cooper (Stanford University) HepG2 cells were maintained in RPMI supplemented with penicillin, streptomycin and glutamine, and containing $10 \%$ fetal bovine serum (Gibco Laboratories, Grand Island, NY).

Collection of conditioned medium. Cells were detached by trypsinization and plated in $16 \mathrm{~mm}$ multiwells (Costar, Cambridge, MA). At confluency, human fibroblasts were washed three times with a 1:1 mixture by volume of Waymouth's medium:DME plus $0.1 \%$ BSA and then incubated in this serum-free medium with or without experimental additions for the indicated times. For HepG2 cells, the cultures were 
washed three times with RPMI, and then incubated in serum-free, BSA-free RPMI with or without experimental additions for the indicated times. At the end of the incubation period, the conditioned medium was centrifuged at $2,000 \mathrm{~g}, 4^{\circ} \mathrm{C}$ for $30 \mathrm{~min}$ and frozen at $-20^{\circ} \mathrm{C}$ until assayed. At the time of media collection, cell counts were determined with a Coulter counter (Coulter Electronics, Hialeah, FL) on four wells for each condition.

Acid chromatography. To obtain binding proteins free of IGF peptide, conditioned media or plasma samples were chromatographed over a Sephadex G-50 column in $1 \%$ formic acid (14). The exclusion volume of the column, which contains no immunoreactive IGF, was pooled, lyophilized, and then resuspended in assay buffer.

Charcoal adsorption assay for IGF binding activity. Measurements of IGF binding activity were determined using a modified assay procedure described by Martin and Baxter (15). Aliquots of media were incubated with ${ }^{125} \mathrm{I}$-IGF-I $(10,000 \mathrm{cpm})$ overnight at $4^{\circ} \mathrm{C}$ in a final volume of $0.5 \mathrm{ml}$ of $50 \mathrm{mM}$ Tris- $\mathrm{HCl}, 0.5 \%$ BSA (pH 7.4). One $\mathrm{ml}$ of $1 \%$ activated charcoal \pm protamine sulfate $(0.2 \mathrm{mg} / \mathrm{ml})$ was added to the tubes, followed by centrifugation at $4^{\circ} \mathrm{C}$ for $30 \mathrm{~min}$. Bound ${ }^{125} \mathrm{I}-\mathrm{IGF}-\mathrm{I}$ in the supernatant was counted in a gamma counter. Unconditioned medium was assayed in parallel and was subtracted from the total bound radioactivity to determine specific IGF binding activity. Doseresponse curves were determined for each experiment, and all samples were studied at a minimum of three different concentrations $(1-20 \mu \mathrm{l})$, each in duplicate. Experimental results presented in the text were those compared at equivalent concentrations, and only where the dose-dependent relationships were linear.

Glycoprotein assay. Glycosylated IGF binding protein species were determined according to the procedure described by Martin and Baxter (15). Samples were incubated with ${ }^{125} \mathrm{I}-\mathrm{IGF}$ at $4^{\circ} \mathrm{C}$ overnight, then $200 \mu \mathrm{g}$ of Con A were added and bound radioactivity precipitated with $17 \%$ PEG:

Western ligand blots. Unreduced conditioned media and plasma samples were electrophoresed through a SDS polyacrylamide gel using a 5-15\% linear gradient (16), and separated proteins were electroblotted onto nitrocellulose filters $(0 . \dot{4} 5-\mu \mathrm{m}$ pore size) using a BioTrans Unit (Gelman Sciences, Ann Arbor, MI). Filters were blocked, labeled with ${ }^{125} \mathrm{I}-\mathrm{IGF}-\mathrm{I}$ or ${ }^{125} \mathrm{I}-\mathrm{IGF}-\mathrm{II}$ overnight at $4^{\circ} \mathrm{C}$, and visualized by autoradiography, according to the method of Hossenlopp et al. (17).

Northern analysis. Total cellular RNA was isolated from human fibroblasts and HepG2 cells using the guanidine monothiocyanate/ lithium chloride method, and polyadenylated RNA prepared by chromatography on oligo(dT)-cellulose (18). Northern analyses of the samples were performed, as detailed previously (19). RNA was electrophoresed in a $1.2 \%$ agarose-formaldehyde gel and transferred to nitrocellulose membranes. The membranes were baked at $80^{\circ} \mathrm{C}$ for 2 $\mathrm{h}$, prehybridized at $42^{\circ} \mathrm{C}$ for $2 \mathrm{~h}$, and hybridized at $42^{\circ} \mathrm{C}$ overnight with $1 \times 10^{7} \mathrm{cpm}$ of a ${ }^{32} \mathrm{P}$-labeled $367 \mathrm{bp}$ fragment of the $3^{\prime}$ coding region of a HepG2 IGF binding protein cDNA probe (19). The fragment was obtained by digestion of the CDNA with Bam HI and PST I. The membranes were washed, air dried, and exposed to Kodak XAR-2 film for autoradiography. The integrity of the RNA was assessed by ethidium bromide staining of the gel.

\section{Results}

Effect of protamine sulfate on IGF binding protein activity. When conditioned medium from human fibroblast cultures was incubated with ${ }^{125} \mathrm{I}$-IGF-I overnight at $4^{\circ} \mathrm{C}$, and then $1 \%$ activated charcoal added, little or no bound ${ }^{125} \mathrm{I}-\mathrm{IGF}-\mathrm{I}$ was evident in the resulting supernatant, even using $100 \mu \mathrm{l}$ of conditioned medium, suggesting no IGF binding activity in the medium (Fig. 1). Under identical incubation and assay conditions, maximum IGF binding protein activity ( $26 \%$ specifically bound $\left.{ }^{125} \mathrm{I}-\mathrm{IGF}-\mathrm{I}\right)$ was found with only $25 \mu \mathrm{l}$ of HepG2 conditioned medium. Dramatically different results were obtained

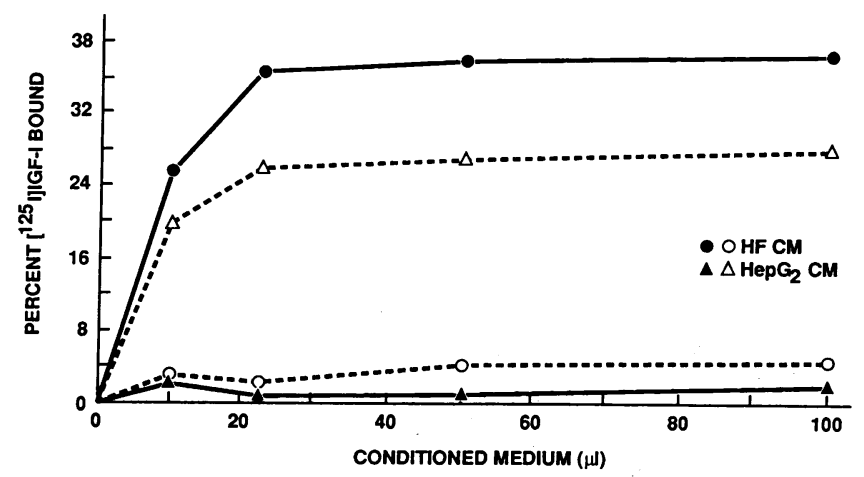

Figure 1. IGF binding assay: effect of protamine sulfate. Aliquots of conditioned medium from human fibroblast $(\bullet \circ)$ or HepG2 $(\Delta \Delta)$ cultures were incubated with ${ }^{125} \mathrm{I}$-IGF-I overnight at $4^{\circ} \mathrm{C}$. At the end of the incubation period, $1 \%$ activated charcoal without (open symbols, broken lines) or with (closed symbols, solid lines) $0.2 \mathrm{mg} / \mathrm{ml}$ protamine sulfate was added, followed by centrifugation. Results are expressed as percentage of total ${ }^{125}$ I-IGF-I added that is specifically bound in the supernatant. Data points are means of triplicate determinations.

when protamine sulfate $(0.2 \mathrm{mg} / \mathrm{ml})$ was added to the $1 \%$ activated charcoal. When assayed under these conditions, conditioned media from human fibroblast cultures demonstrated high IGF binding protein activity. Near maximal binding (26\%) was seen with $10 \mu \mathrm{l}$ conditioned medium from human fibroblasts. In contrast, addition of protamine sulfate to the activated charcoal resulted in the apparent loss of all detectable IGF binding activity in the condition medium from HepG2 cultures. When IGF-II was used as the radioligand, similar results were observed (data not shown).

While investigating this assay phenomenon further, it became apparent that soluble IGF binding proteins could be separated into two classes depending upon the effect of protamine sulfate on the IGF binding assay (Table I). Activity that was enhanced (2- to 40 -fold) when $1 \%$ activated charcoal plus protamine sulfate was used included IGF binding protein activity in conditioned media from fetal and postnatal human fibroblasts, human breast cancer cells, rat neuroblastoma cells, BRL3A2 cells, and ovine thyroid cells, and normal adult human plasma. Acid chromatography of the human plasma, to obtain binding protein free of IGF peptide (14), resulted in even greater apparent IGF binding activity, as determined using $1 \%$ charcoal in presence of protamine sulfate. Activity that was attenuated when $1 \%$ charcoal plus protamine sulfate was used included IGF binding protein activity in the conditioned medium of HepG2 cells and in amniotic fluid, as well as purified IGF binding proteins from these two sources. There was general concordance between the protamine sulfate data for the different IGF binding proteins and their affinity for Con A (Table I, see below).

In subsequent experiments, IGF binding protein activity in human fibroblast medium was assayed with $1 \%$ activated charcoal + protamine sulfate $(0.2 \mathrm{mg} / \mathrm{ml})$, and HepG2 binding protein activity was determined with $1 \%$ activated charcoal alone. The use of protamine sulfate did not affect the binding kinetics, ${ }^{2}$ and IGF binding protein activity determined under

2. Rosenfeld, R. G., H. Pham, C. A. Conover, and R. L. Hintz. Manuscript submitted for publication. 
Table I. Effect of Assay Conditions on Apparent IGF Binding Activity

\begin{tabular}{lcccc}
\hline & \multicolumn{4}{c}{ IGF binding activity (\%) } \\
\cline { 3 - 5 } & $n$ & $(-)$ PS $^{*}$ & $(+) P S$ & Con A $^{*}$ \\
\hline Conditioned media & & & & \\
Human fibroblasts & & & & \\
$\quad$ GM3652A (adult) & 9 & $2 \pm 0.5$ & $30 \pm 1.7$ & 22 \\
CRL1564 (adult) & 1 & 3 & 38 & 21 \\
CRL1493 (adult) & 2 & 2 & 26 & ND \\
GM10 (fetal) & 1 & 6 & 30 & ND \\
AG4392 (fetal) & 1 & 6 & 32 & ND \\
AG4449 (fetal) & 1 & 6 & 37 & ND \\
HepG2 & 6 & $22 \pm 2.8$ & $1 \pm 0.3$ & 0 \\
Breast carcinoma (human) & 2 & 11 & 27 & 16 \\
Neuroblastoma (rat) & 2 & 7 & 46 & ND \\
Thyroid cells (ovine) & 3 & $8 \pm 0.9$ & $22 \pm 2.5$ & 21 \\
BRL3A2 & 4 & $5 \pm 1.4$ & $47 \pm 4.8$ & 14 \\
Biological fluids & & & & \\
Human plasma & 2 & 2 & 10 & ND \\
Human plasma (AC) & 4 & $1 \pm 0.2$ & $41 \pm 0.8$ & 45 \\
Amniotic fluid & 4 & $18 \pm 1.9$ & $5 \pm 1.5$ & 1 \\
Purified BP & & & & \\
HepG2 & 1 & 18 & 3 & ND \\
Amniotic fluid & 1 & 17 & 4 & ND \\
& & & & \\
\hline
\end{tabular}

Samples $(10 \mu \mathrm{l})$ were incubated with ${ }^{125} \mathrm{I}-\mathrm{IGF}$-I overnight at $4^{\circ} \mathrm{C}$.

* IGF binding activity was determined by adsorption with $1 \%$ activated charcoal in the presence or absence of protamine sulfate (PS; $0.2 \mathrm{mg} / \mathrm{ml}$ ), as described in Fig. 1. Results (means \pm SEM of $n$ experiments) are expressed as percentage of total ${ }^{125}$ I-IGF-I added which is specifically bound in the supernatant.

\# Glycosylated IGF binding proteins were determined by addition of $200 \mu \mathrm{g}$ Con A, followed by precipitation with 17\% PEG as described in Methods. Results (average of two experiments) are expressed as percentage of total ${ }^{125}$ I-IGF-I added which is specifically precipitated. Human breast carcinoma, MCF7 (41); rat neuroblastoma, B104 (42); ovine thyroid cells, primary culture (43); BRL3A2, Buffalo rat liver cell line (44); human plasma (AC), acid-chromatographed before assay; HepG2 and amniotic fluid binding proteins were purified according to published procedures $(7,35)$.

these respective assay conditions was specific. In competitive binding studies, $50 \%$ displacement of ${ }^{125} \mathrm{I}-\mathrm{IGF}-\mathrm{I}$ from binding protein in human fibroblast conditioned medium was achieved with $0.2 \mathrm{ng} / \mathrm{ml}$ unlabeled IGF-I or IGF-II. When IGF-II was used as the radioligand, unlabeled IGF-II appeared to be slightly more potent than IGF-I, with $50 \%$ displacement at 0.6 and $2.5 \mathrm{ng} / \mathrm{ml}$ unlabeled IGF-II and IGF-I, respectively (data not shown). These results are similar to those reported by Adams et al. (9). This specificity and relative affinity have also been found for the growth-hormone-dependent IGF binding protein in human plasma (15). In contrast, HepG2 conditioned medium bound IGF-I and IGF-II equivalently with 10-fold lower affinity. ${ }^{2}$ Insulin at $10 \mu \mathrm{g} / \mathrm{ml}$ did not compete with either ${ }^{125} \mathrm{I}-\mathrm{IGF}$-I or -II for binding to human fibroblast or HepG2 conditioned medium (data not shown).

Time course of IGF binding protein production. Fig. 2 shows that IGF binding protein activity is apparent in the conditioned medium of human fibroblasts at $6 \mathrm{~h}$ of incubation at $37^{\circ} \mathrm{C}$, and increases over time. When medium was serially collected and the medium replaced, as indicated by the $18-\mathrm{h}$ time bars, the rate of production of human fibroblast IGF binding protein activity was relatively constant over a 72-h incubation period. Conditioned medium collected at 6-24, 30-48, and 52-72 h, and assayed at equivalent submaximal concentrations, bound $18 \%, 19 \%$, and $16 \%$ of added ${ }^{125} \mathrm{I}-\mathrm{IGF}$ I, respectively.

HepG2 IGF binding protein production was also time dependent. Little or no binding protein activity was detectable in the medium at $6 \mathrm{~h}$, but a steady increase in activity was observed over the next $72 \mathrm{~h}$. When medium from HepG2 cultures was repetitively collected and replaced, the 18 -h production rate was relatively low (4-6\% ${ }^{125}$ I-IGF-I bound) at all three time periods. HepG2 cells appeared to require an undisturbed state to efficiently produce and secrete IGF binding protein, in contrast to human fibroblasts which, despite frequent media changes, were able to rapidly synthesize new IGF binding protein. IGF binding protein released by human fibroblasts in the first $6 \mathrm{~h}$ may be from previously sequestered calf serum or represent preformed membrane-associated binding protein, since activity was apparent in the medium when fibroblasts were incubated at $4^{\circ}$ and $15^{\circ} \mathrm{C}$, temperatures at which protein synthesis was inhibited (data not shown). Therefore, in subsequent experiments, serum-free medium conditioned during the first $6 \mathrm{~h}$ was discarded and the cells washed again before addition of fresh serum-free medium with or without experimental additions. This protocol was especially important for the hormonal control studies (see below), where the presence of unregulated binding protein in the medium might mask any observed effects.

Glycosylated IGF binding proteins. To determine whether one or more of the IGF binding proteins secreted by human

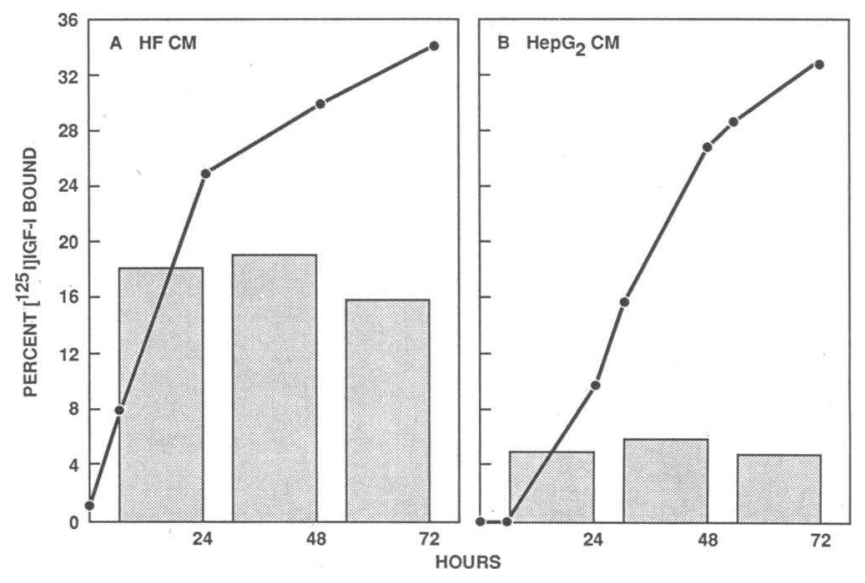

Figure 2. Time course of secretion of IGF binding protein activity. Confluent cultures were washed three times, and serum-free medium added at $0 \mathrm{~h}$. Conditioned medium was collected either from different wells at each time point (solid lines) or sequentially from the same wells for the indicated time periods (shaded bars). For the sequential collection, media was collected, the cells washed and incubated for $6 \mathrm{~h}$ in serum-free medium, and the serum-free medium then replaced for an additional $18 \mathrm{~h}$ incubation. IGF binding protein activity was determined by adsorption with $1 \%$ activated charcoal with $0.2 \mathrm{mg} / \mathrm{ml}$ protamine sulfate ([A] HF CM, human fibroblast conditioned medium) or without protamine sulfate ( $[B]$ HepG2 conditioned medium), as described in Fig. 1. Results are expressed as percent of total ${ }^{125}$ I-IGF-I added that is specifically bound in the supernatant. Values for $10 \mu \mathrm{l}$ of conditioned medium are presented. 
fibroblasts were glycosylated, conditioned medium was incubated with ${ }^{125} \mathrm{I}-\mathrm{IGF}-\mathrm{I}$, allowed to interact with Con A, and then precipitated with PEG. Human fibroblast IGF binding protein was precipitated by this methodology $\left(\sim 20 \%\right.$ of total ${ }^{125} \mathrm{I}$ IGF-I was specifically precipitated), while there was no detectable IGF binding protein species that was precipitated from HepG 2 conditioned medium or amniotic fluid. Other binding proteins species tested which bound to Con A included those from MCF-7 breast carcinoma cells, BRL3A2 cells, thyroid cultures, and human plasma, as indicated in Table $\mathrm{I}$.

Hormonal regulation of IGF binding protein activity. The effect of various hormones and growth factors on the secretion of IGF binding proteins by cultured human fibroblasts was investigated, and the results presented in Table II. IGF binding protein activity in human fibroblast conditioned medium appeared to be growth hormone dependent. At early time points (6-24 h), a 30\% increase in IGF binding protein activity was observed in medium from cultures treated with growth hormone $(1 \mu \mathrm{g} / \mathrm{ml})$, as compared with medium from control cul-

Table II. Hormonal Control of Human Fibroblast IGF Binding Protein Production

\begin{tabular}{lrrrr}
\hline & \multicolumn{4}{c}{ IGF binding activity (\% control)* } \\
\cline { 2 - 5 } & \multicolumn{1}{c}{$6-24 \mathrm{~h}$} & $24-30 \mathrm{~h}$ & $30-48 \mathrm{~h}$ & $24-72 \mathrm{~h}$ \\
\hline GH & $129 \pm 7(5)$ & $105(1)$ & $112(1)$ & $106(1)$ \\
GH (AC) & $158 \pm 26(3)$ & & $200(1)$ & $135(2)$ \\
DEX & $49 \pm 4(5)$ & $53 \pm 2(5)$ & $52 \pm 9(4)$ & $58 \pm 3(3)$ \\
DEX (AC) & $47(1)$ & $48(2)$ & $50(1)$ & $55(1)$ \\
HC & & $57(2)$ & $29(1)$ & $54(1)$ \\
HC (AC) & & $50(1)$ & & $46(1)$ \\
P & & $116(2)$ & $125(1)$ & $100(1)$ \\
P (AC) & & $105(1)$ & & $106(1)$ \\
E & & $125(2)$ & $133(1)$ & $107(1)$ \\
E (AC) & & $100(1)$ & & $104(1)$ \\
T & & $96(2)$ & $110(1)$ & $100(1)$ \\
T (AC) & & $95(1)$ & & $103(1)$ \\
EGF & & $100(1)$ & $98(1)$ & \\
EGF (AC) & & $90(1)$ & $133(1)$ & \\
PDGF & & $105(1)$ & $104(1)$ & \\
PDGF (AC) & & $123(1)$ & & $96(2)$ \\
Ins & $117 \pm 16(3)$ & & & \\
Ins (AC) & $92(1)$ & & & \\
& & &
\end{tabular}

Confluent human fibroblast cultures were washed three times, and then incubated for the indicated times in Waym:DME/0.1\%

$\mathrm{BSA} \pm$ peptides. IGF binding activity was determined by adsorption with $1 \%$ activated charcoal in the presence of $0.2 \mathrm{mg} / \mathrm{ml}$ protamine sulfate, as described in Fig. 1, and corrected for any changes in cell number due to growth factor treatment. Samples $(1-20 \mu \mathrm{l})$ of conditioned medium from various treatments were assayed and results of experiments compared at equal concentrations of media, where dosedependent relationships were linear.

* Values (means \pm SEM of $[n]$ experiments) are presented as percentage of IGF binding activity in control (untreated) cultures, which was 9-15\% ${ }^{125}$ I-IGF-I bound.

$\mathrm{GH}$, growth hormone ( $1 \mu \mathrm{g} / \mathrm{ml})$; DEX, dexamethasone (100 nM); $\mathrm{HC}$, hydrocortisone $(1 \mu \mathrm{M}) ; \mathrm{P}$, progesterone $(1 \mu \mathrm{M})$; E, beta estradiol $(1 \mu \mathrm{M})$; T, testosterone (1 $\mu \mathrm{M})$; EGF, epidermal growth factor (10 $\mathrm{ng} / \mathrm{ml}) ;$ PDGF, platelet derived growth factor $(0.5 \mathrm{U} / \mathrm{ml})$; Ins, insulin $(1 \mu \mathrm{g} / \mathrm{ml}) ;(\mathrm{AC})$ indicates acid-chromatographed sample.

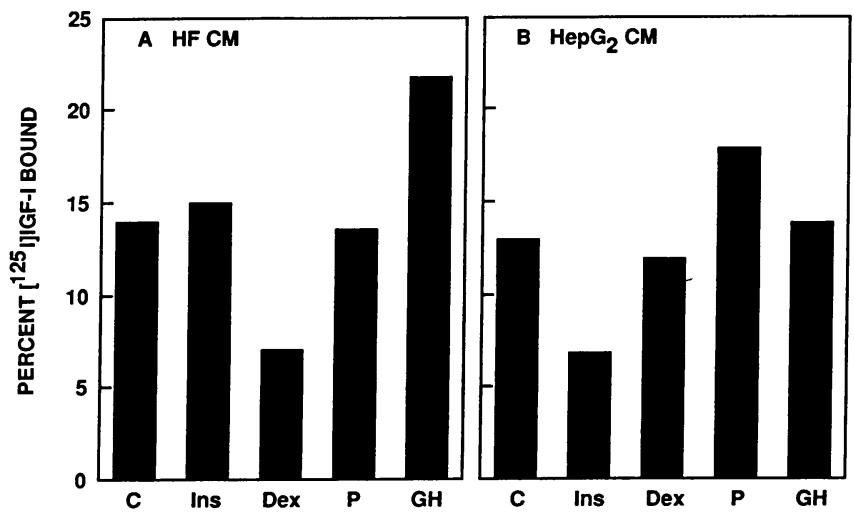

Figure 3. Hormonal regulation of IGF binding protein production. Human fibroblasts $(A)$ and HepG2 cells $(B)$ were treated with hormones, the medium collected at 6-24 h, and IGF binding activity assayed, as described in Table II. Dose-response curves were determined for each medium sample. Values presented are for $10-\mu 1$ samples (determined to be on the linear portion of the dose response curve) expressed as percentage of total ${ }^{125}$ I-IGF-I added which is specifically bound, and corrected for any changes in cell number. $\mathrm{C}$, control; Ins, insulin $(1 \mu \mathrm{g} / \mathrm{ml})$; Dex, dexamethasone (100 nM); P, progesterone (1 $\mu \mathrm{M})$; $\mathrm{GH}$, growth hormone $(1 \mu \mathrm{g} / \mathrm{ml})$.

tures. At later incubation times ( $>24 \mathrm{~h}$ ) there was no apparent increase in IGF binding protein activity with growth hormone treatment relative to control. However, when media samples were first acid-chromatographed to remove IGF peptides, growth hormone-treated cells demonstrated a $35-100 \%$ increase in IGF binding protein activity.

The IGF binding protein activity was markedly diminished when fibroblasts were treated with glucocorticoids. At all time points, dexamethasone $(100 \mathrm{nM})$ or hydrocortisone $(1 \mu \mathrm{M})$ decreased IGF binding protein activity in the conditioned medium $\sim 50 \%$. This effect was specific for glucocorticoids, since other steroids, including progesterone, estradiol, and testosterone, had no effect on fibroblast IGF binding protein production. EGF, PDGF, and insulin also had no consistent effect on human fibroblast IGF binding protein production. Acid-chromatography of these conditioned medium samples showed little or no alteration of IGF binding protein activity. The presence of the steroids and peptides tested had no direct effect in the IGF binding protein assay (data not shown).

Fig. 3 presents an experiment where the patterns of hormonal regulation of human fibroblast and HepG2 IGF binding proteins were directly compared. Growth hormone treatment increased IGF binding protein production $57 \%$ by human fibroblasts. Dexamethasone suppressed IGF binding protein production $50 \%$, while insulin and progesterone had no effect in these cultures. Thus, the results of this experiment were representative of the hormonal control of human fibroblast IGF binding protein secretion as summarized in Table II. In contrast, HepG 2 binding protein production was diminished $50 \%$ by insulin treatment and enhanced $30 \%$ by progesterone. Dexamethasone and growth hormone had no effect on HepG2 binding protein production. Three additional experiments were performed in HepG 2 cultures with the following values for IGF binding activity (percent of control, mean \pm SEM) in 6-48 $\mathrm{h}$ media for the indicated hormonal additions: dexamethasone $(95 \pm 5 \%)$, insulin $(63 \pm 9 \%)$, progesterone $(156 \pm 18 \%)$, and growth hormone $(93 \pm 6 \%)$. 

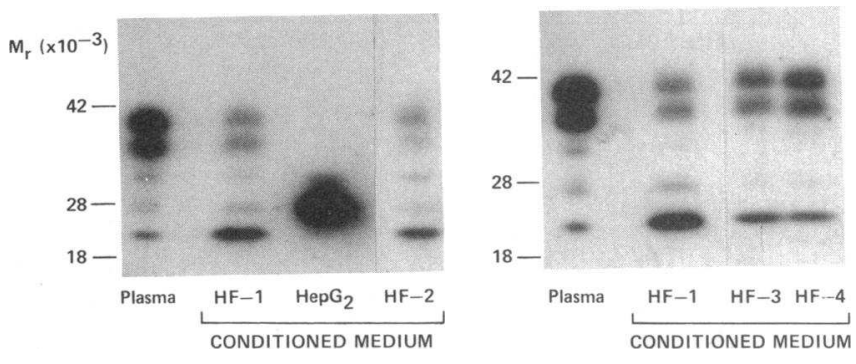

Figure 4. Western ligand blots of IGF binding proteins. Normal human plasma and conditioned media samples were separated on a $5-15 \%$ gradient SDS-polyacrylamide gel under nonreducing conditions, electroblotted onto nitrocellulose filters, and after incubation with ${ }^{125}$ I-IGF-I, identified by autoradiography. HF CM 1-4: Human fibroblast conditioned medium from cultures designated GM3652A, AG4449, CRL1564, and AG4392, respectively (see Table I).

Western ligand blotting. Fig. 4 shows the migration of IGF binding protein species from human plasma, human fibroblast conditioned medium, and HepG2 conditioned medium after SDS-PAGE (nonreducing conditions), transfer onto nitrocellulose and incubation with ${ }^{125}$ I-IGF-I. In normal plasma, five bands emerged: two major bands of $M_{\mathrm{r}}=41,500$ and 37,000, and three fainter bands of $M_{\mathrm{r}}=32,000,28,000$, and 23,000 which by densitometric analysis accounted for $50 \%, 38 \%, 4 \%$, $3 \%$, and $5 \%$ of the total ${ }^{125}$ I-IGF-I bound, respectively. Conditioned medium from cultured human fibroblasts contained the same five forms of IGF binding proteins seen in normal human plasma, although their proportions were different. In human fibroblast conditioned medium, the $M_{\mathrm{r}}=23,000$ binding protein species was more apparent $(20-60 \%$ of the total ${ }^{125}$ I-IGF-I bound), although the $M_{\mathrm{r}}=41,500$ and 37,000 were still abundant and together accounted for $30-70 \%$ of the total ${ }^{125}$ I-IGF-I bound. When media from various human fibroblast lines were analyzed, the migratory profiles were similar, with no significant differences between fetal and postnatal lines. With HepG2 conditioned medium, a $M_{\mathrm{r}}=28,000$ band was heavily labeled, with a small "cap" at $M_{\mathrm{r}}=32,000$. The specificity of these bands was confirmed by their inhibition in the presence of excess unlabeled IGF (data not shown). When ${ }^{125}$ I-IGF-II was employed as the radioligand, the only major change was an increase in intensity of the $M_{\mathrm{r}}=28,000$ band in plasma and human fibroblast conditioned media samples (data not shown).

Western ligand blots of the conditioned medium from hormone treated human fibroblasts revealed that the $M_{\mathrm{r}}$ $=41,500,37,000,28,000$, and 23,000 IGF binding proteins appeared to be regulated concordantly (Fig. 5). By densitometric analysis, treatment of cells with dexamethasone showed a $20-50 \%$ reduction in labeling intensity in the four bands, while growth hormone treatment resulted in a $42-50 \%$ increase in the four bands. The $M_{\mathrm{r}}=32,000$ bands were very faint and did not appear to be affected by either glucocorticoid or growth hormone treatment.

Northern analysis. Northern analysis of RNA extracted from HepG2 cells and human fibroblasts is shown in Fig. 6. Hybridization of HepG2 RNA with a ${ }^{32}$ P-labeled fragment of the cDNA probe for the $M_{\mathrm{r}}=28,000$ HepG2 IGF binding protein identified a predominant band, indicating a transcript size of $1.65 \mathrm{~kb}$, as reported by Lee et al. (19). RNA isolated from four different lines of fetal and postnatal human fibro-

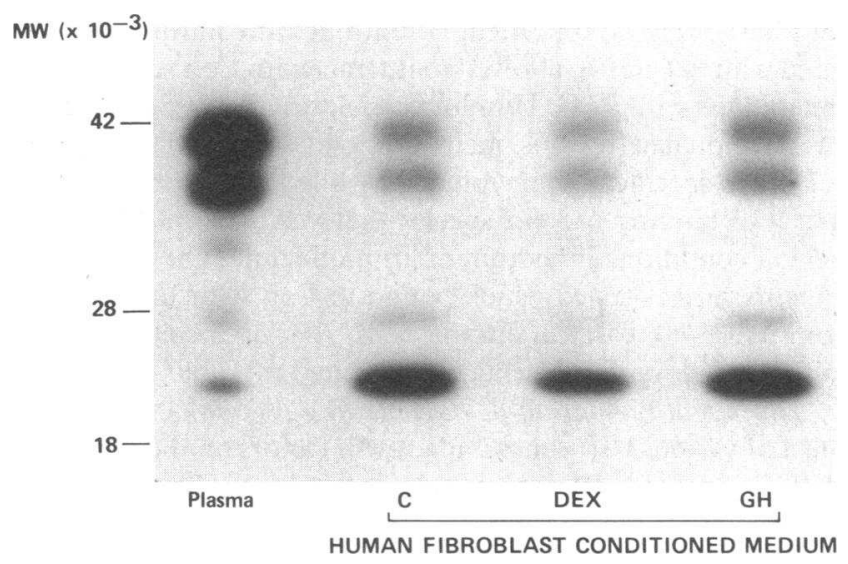

Figure 5. Western ligand blot: hormonal regulation of human fibroblast IGF binding proteins. Normal human plasma and conditioned media samples from the experiment presented in Fig. 3 were electrophoresed through a 5-15\% SDS-polyacrylamide gel, transferred onto nitrocellulose filters, incubated with ${ }^{125}$ I-IGF-I, and visualized by autoradiography. C, control; Dex, dexamethasone (100 nM); GH, growth hormone $(1 \mu \mathrm{g} / \mathrm{ml})$.

blasts, as well as poly(A) ${ }^{+}$RNA prepared from one fibroblast line, did not show any hybridization to the cDNA probe for HepG2 IGF binding protein. Conditioned medium from these same fibroblast cultures had abundant IGF binding protein activity (data not shown).

\section{Discussion}

Human fibroblasts in culture secrete low molecular weight IGF binding proteins which are structurally, biochemically, and physiologically distinct from the $M_{\mathrm{r}}=28,000 \mathrm{HepG} 2 / \mathrm{am}$ niotic fluid IGF binding protein, but which share many of the characteristics of the predominant big IGF binding protein complex in normal adult human plasma.

The data presented here indicate that IGF binding protein secretion is under specific hormonal control. Human fibroblast IGF binding protein production is increased by growth hormone treatment, similar to the major $M_{\mathrm{r}}=150,000$ IGF

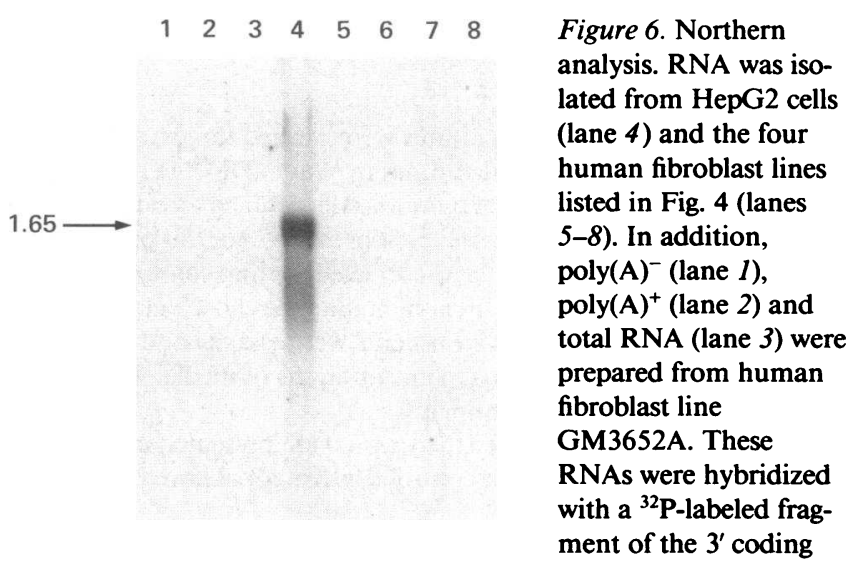

region of the HepG2 IGF binding protein cDNA probe before exposure to film for autoradiography. An RNA ladder from BRL was used as markers. The arrow indicates an mRNA transcript size of $\sim 1.65 \mathrm{~kb}$ 
binding protein complex in human plasma $(3,20)$. As measured by radioligand binding assays, this growth hormone effect was not consistently observed unless the medium was first acid-chromatographed. This step would remove any interference to equilibration of binding proteins with ${ }^{125} \mathrm{I}$-IGFs by endogenous IGF peptides which may be produced and released by human fibroblasts under growth hormone stimulation (21). In contrast, Adams et al. did not observe any effect of growth hormone on IGF binding activity in human fibroblast conditioned medium (9). Although the reason(s) for the differences are unclear, their methodology differed from ours in two essential ways: ( $a$ ) The conditioned medium was not acidchromatographed to remove endogenous IGFs before assay, and $(b)$ the amount of control conditioned medium assayed gave near maximal IGF binding activity, so that any increase with growth hormone treatment might not have been detected. In our study we were careful to assay and compare conditioned media at a minimum of three concentrations to determine the linear portion of the IGF binding assay curve where increases in activity could be easily measured.

It is interesting that IGF binding protein secretion by human fibroblasts was markedly suppressed by glucocorticoids. Serum IGF carrier protein levels were also found to be significantly lower than normal in untreated Cushing's syndrome patients, and close to normal after glucocorticoid therapy (22). Glucocorticoids have been shown to act synergistically with IGF-I to stimulate DNA synthesis and replication of human fibroblasts by mechanisms as yet unknown (2). Modulation of IGF binding proteins by glucocorticoids may play a role in this interaction. EGF and PDGF have been reported to influence IGF secretion and to interact with IGF-I in stimulating fibroblast growth $(23,24)$. However, EGF and PDGF had no significant effect on IGF binding protein secretion by human fibroblasts. Insulin also had no effect on IGF binding protein activity in these cells. In contrast, insulin diminished the IGF binding protein activity in HepG 2 conditioned medium. Suikkari et al. have suggested that insulin regulates the amniotic fluid immunoreactive species of IGF binding protein in human plasma (25). They found IGF binding protein levels to be elevated in patients with diabetes and decreased in postprandial and hyperinsulinemic subjects. HepG2 binding protein was not affected by growth hormone, consistent with the non-growth hormone responsiveness of "small" serum IGF binding protein (3). HepG2 binding protein was not affected by glucocorticoids, although it was stimulated by progesterone treatment. Placental protein 12 (PP12), which is related if not identical to the HepG2/amniotic fluid IGF binding protein, was also found to be induced by progesterone in human endometrium (26). Furthermore, preliminary reports suggest that IGF-I can autoregulate the production of particular binding proteins $(27,28)$. Therefore, the various IGF binding protein species are differentially regulated by a variety of hormones and growth factors.

The aforementioned IGF binding activities were determined by charcoal adsorption assays with protamine sulfate in the case of human fibroblast media, and without protamine sulfate for HepG2 media. As confirmed by Western ligand analysis (Fig. 5), IGF binding activity determined under these respective assay conditions accurately reflected qualitative and quantitative differences in IGF binding proteins. Initially, protamine sulfate was introduced into the IGF binding activity assay as a general agent for controlling the charcoal adsorption rate, as suggested by Scott et al. (29). However, under these assay conditions, the presence or absence of protamine sulfate became useful as a method for segregating IGF binding proteins into two classes. Protamine sulfate added during the charcoal separation step enhanced the apparent binding activity from human fibroblast conditioned medium, plasma, and many other sources (see Table I). In contrast, it diminished activity in HepG2 conditioned medium and amniotic fluid. These results not only may help to explain some of the discrepancies in the literature, but also indicate biochemically significant qualitative differences in IGF binding protein species. Protamine sulfate is a highly basic molecule, and when added to the activated charcoal probably "coats" the charcoal, altering its charge and adsorptive qualities. This change in charge could differentially affect interaction with IGF/binding protein complexes, depending upon the charge of the binding protein species, itself, and the affinity of the binding protein for the IGF peptide. Results of PEG precipitation of the supernatant from the charcoal separation assay indicated that, in the case of HepG2 IGF binding protein, protamine sulfate permitted the charcoal to adsorb bound IGF (data not shown). It may be relevant that the amniotic fluid/HepG2 IGF binding protein has been shown to have a lower proportion of basic amino acids than the acid-stable growth hormone-dependent IGF binding protein from human plasma (30). Also, differential reaction to protamine sulfate may be associated with the glycosylation state of the IGF binding protein species. At least one form of IGF binding protein from human fibroblasts is glycosylated, as is the big IGF binding protein in plasma and other IGF binding proteins that have been identified as protamine sulfate responsive from MCF-7 breast carcinoma, BRL3A2 cells, and thyroid tissue (Table I). The IGF binding proteins isolated from HepG2 cells and amniotic fluid do not appear to possess glycosylated moieties (Table I and 31). A difference in charge amongst the IGF binding protein species was also noted by Hardouin et al. (32). In chromatofocusing experiments, they reported that the molecular forms associated with the big $M_{\mathrm{r}}=150,000$ binding protein in plasma focused predominantly at $\mathrm{pH} \geq 7.0$, while the $M_{\mathrm{r}}=30,000$ form in amniotic fluid eluted at $\mathrm{pH} \leq 4.5$.

Western ligand blotting permitted electrophoretic identification of protein subunits which specifically bind IGFs. ${ }^{125} \mathrm{I}$ IGF-I binding to the transferred proteins from human fibroblast medium, resulted in the identification of five bands at $M_{\mathrm{r}}$ $=41,500,37,000,32,000,28,000$, and 23,000. These are similar in size to the five species of IGF binding proteins classified by this method in human plasma, cerebrospinal fluid, and conditioned medium from liver explants (32-34). The $M_{\mathrm{r}}$ $=41,500$ and 37,000 species accounted for $30-70 \%$ of the IGF binding proteins secreted by human fibroblasts, and have been shown to be associated with the growth hormone-dependent $M_{\mathrm{r}}=150,000$ binding protein complex predominant in human plasma (32). These two forms may be related since Baxter et al. purified the acid-stable subunit of the growth hormone-dependent plasma IGF binding protein and showed that the two bands on analytical electrophoresis had only a single unambiguous amino-terminus sequence (30). The $M_{\mathrm{r}}$ $=23,000$ species accounted for $20-60 \%$ of secreted human fibroblast IGF binding proteins. This is in contrast to plasma, where it is a minor component representing $\sim 5 \%$ of total IGF binding proteins. Human fibroblasts do not secrete the HepG2/amniotic fluid form of IGF binding protein, since 
(a) No immunologically reactive IGF binding protein in human fibroblast conditioned medium was detected using specific polyclonal antiserum (35) and monoclonal antibodies (36) for the HepG2/amniotic fluid IGF binding protein (data not shown); (b) Synthesis of a $M_{\mathrm{r}}=28,000$ IGF binding protein by human fibroblasts was suppressed by dexamethasone and increased with growth hormone treatment, unlike the hormonal regulation of HepG 2 IGF binding protein production, which is unresponsive to these growth factors; (c) RNA extracted from human fibroblasts did not hybridize with a HepG2 IGF binding protein cDNA probe. Therefore, human fibroblast IGF binding proteins are distinct gene products from the HepG2/amniotic fluid IGF binding protein.

Thus, human fibroblasts appear to produce primarily the molecular forms corresponding to the $M_{\mathrm{r}}=150,000 \mathrm{IGF}$ binding protein complex $\left(M_{\mathrm{r}}=41,500\right.$ and 37,000$)$, as well as an $M_{\mathrm{r}}=23,000$ product. The nature of the growth hormone-dependent $M_{\mathrm{r}}=23,000$ IGF binding protein species, which is predominant in many human fibroblast lines, and its relationship to the $M_{\mathrm{r}}=41,500$ and 37,000 subunits are unknown. Hossenlop et al. found an $M_{\mathrm{r}}=24,000$ species to be increased in acromegalic serum, although it did not appear to be directly associated with the growth hormone-dependent big IGF binding protein complex (32). Wilkins and D'Ercole reported that an affinity labeled $M_{\mathrm{r}}=24,000-28,000$ IGF binding protein subunit varied with growth hormone status (4). Studies are in progress to purify and derive an amino acid sequence for the $M_{\mathrm{r}}=23,000 \mathrm{IGF}$ binding protein from human fibroblast conditioned media, and to determine its relationship to other forms of IGF binding proteins.

One question not directly addressed in this study concerns the possible association of these molecular forms in native human fibroblast secretions as an oligomeric binding protein complex, such as that found in plasma. The methodologies utilized in this study identified only the monomeric units of human fibroblast IGF binding protein. These units are individually capable of binding IGFs, as evidenced by Western ligand blots. Cerebrospinal fluid and conditioned medium from cultured human liver also were shown to contain all five molecular forms of IGF.binding protein, with no apparent large complexes $(33,34)$. Therefore, although human fibroblast conditioned medium contains the same basic subunits as the plasma high molecular weight IGF binding complex, additional factor(s) may be required for association. Nevertheless, Adams et al. have reported IGF binding activity in human fibroblast conditioned medium, which eluted in the void volume $\left(M_{\mathrm{r}}>100,000\right)$ of a neutral Sephadex G-150 column (9).

The precise role of IGF binding proteins in IGF physiology is unclear (3). These binding proteins have been shown to prolong the serum half life of IGF-I and IGF-II, and to protect the body from excess insulin-like activity. They may also monitor tissue selectivity and delivery of IGFs to the interstitial space. Moreover, recent evidence of the synthesis and secretion of IGF binding proteins by cells, themselves, suggests they may play an important active role in the regulation of biological action. At the cellular level, IGF binding proteins have been described to have both inhibitory and stimulatory effects $(11,37-39)$. No studies have been reported to date on the effects of purified plasma binding protein, although a truncated form of IGF-I, which has reduced affinity for plasma binding proteins, had 10-fold greater bioactivity than intact IGF-I (40). These studies, along with the present demonstra- tion of specific hormonal regulation of discrete IGF binding protein species, suggest that IGF binding proteins are complex and highly influential elements in IGF physiology.

Thus, this study further demonstrates that multiple molecular forms of IGF binding proteins exist, and presents evidence that the various forms are subject to different control mechanisms. Human fibroblasts secrete low molecular weight IGF binding proteins, distinct from the HepG2/amniotic fluid IGF binding protein, which are regulated by growth hormone and glucocorticoids in vitro. This detailed characterization of the cultured human fibroblast system will be an important basis for further studies on the transcriptional and translational modulation of IGF binding protein production. Furthermore, the use of fibroblasts from various subjects will provide a valuable model for evaluating the functional significance of IGF binding proteins in normal and pathological physiology.

\section{Acknowledgments}

This work was supported in part by National Institutes of Health grants DK-28229, DK-36054, CA-42106, RCDA-01275, DK-38773, and DK-24085.

\section{References}

1. Froesch, E. R., C. Schmid, J. Schwander, and J. A. Zapf. 1985. Actions of insulin-like growth factors. Rev. Physiol. 47:443-467.

2. Conover, C. A., L. A. Dollar, R. L. Hintz, and R. G. Rosenfeld. 1983. Insulin-like growth factor $\mathrm{I} /$ somatomedin $\mathrm{C}$ and glucocorticoids synergistically regulate mitosis in competent human fibroblasts. $J$. Cell. Physiol. 116:191-197.

3. Hintz, R. L. 1984. Plasma forms of somatomedin and the binding protein phenomenon. Clinics Endocrinol. Metab. 13:31-42.

4. Wilkins, J. R., and A. J. D'Ercole. 1985. Affinity-labeled plasma somatomedin-C/insulin-like growth factor I binding protein. J. Clin. Invest. 75:1350-1358.

5. Furlanetto, R. W. 1980. The somatomedin C binding protein: Evidence for a heterologous subunit structure. J. Clin. Endocrinol. Metab. 51:12-19.

6. Povoa, G., G. Enberg, H. Jornvall, and K. Hall. 1984. Isolation and characterization of a somatomedin binding protein from midterm amniotic fluid. Eur. J. Biochem. 144:199-204.

7. Powell, D. R., P. D. K. Lee, J. E. Shively, M. Eckenhausen, and R. L. Hintz. 1987. Method for purification of an insulin-like growth factor binding protein produced by human HEPG2 hepatoma cells. $J$. Chromatogr. 420:163-170.

8. Povoa, G., M. Isaksson, H. Jornvall, and K. Hall. 1985. The somatomedin binding protein isolated from a human hepatoma cell line is identical to human amniotic fluid somatomedin binding protein. Biochem. Biophys. Res. Commun. 128:1071-1078.

9. Adams, S. O., M. Kapadia, B. Mills, and W. H. Daughaday. 1984. Release of insulin-like growth factors and binding protein activity into serum-free medium of cultured human fibroblasts. Endocrinology. 115:520-526.

10. Clemmons, D. R., R. G. Elgin, V. K. M. Hans, S. J. Casella, A. J. D'Ercole, and J. J. Van Wyk. 1986. Cultured fibroblast monolayers secrete a protein that alters the cellular binding of somatomedin-C/insulinlike growth factor I. J. Clin. Invest. 77:1548-1556.

11. Elgin, R. G., W. H. Busby, Jr., and D. R. Clemmons. 1987. An insulin-like growth factor (IGF) binding protein enhances the biologic response to IGF-I. Proc. Natl. Acad. Sci. USA. 84:3254-3258.

12. Hunter, W. M., and F. C. Greenwood. 1962. Preparation of iodine-131 labeled human growth hormone of high specific activity. Nature (Lond.). 194:495-496. 
13. Gavin, J. R. III, J. Roth, P. Jen, and P. Frechet. 1972. Insulin receptors in human circulating cells and fibroblasts. Proc. Natl. Acad. Sci. USA. 69:747-751.

14. Horner, J. M., F. Liu, and R. L. Hintz. 1978. Comparison of ${ }^{125} \mathrm{I}$-somatomedin $\mathrm{A}$ and ${ }^{125} \mathrm{I}$-somatomedin $\mathrm{C}$ radioreceptor assays for somatomedin peptide content in whole and acid-chromatographed plasma. J. Clin. Endocrinol. Metab. 47:1287-1295.

15. Martin, J. L., and R. C. Baxter. 1986. Insulin-like growth factor-binding protein from human plasma: purification and characterization. J. Biol. Chem. 261:8754-8760.

16. Laemmli, U. K. 1970. Cleavage of structural proteins during assembly of the head of bacteriophage $\mathrm{T}_{4}$. Nature (Lond.). 227:680685.

17. Hossenlopp, P., D. Seurin, B. Segovia-Quinson, S. Hardouin, and M. Binoux. 1986. Analysis of serum insulin-like growth factor binding proteins using western blotting. Use of the method for titration of the binding proteins and competitive binding studies. Anal. Biochem. 154:138-143.

18. Aviv, H., and P. Leder. 1972. Purification of biologically active globin messenger RNA by chromatography on oligothymidylic acid cellose. Proc. Natl. Acad. Sci. USA. 69:1408-1411.

19. Lee, Y.-L., R. L. Hintz, P. M. James, P. D. K. Lee, J. E. Shively, and D. R. Powell. 1988. Insulin-like growth factor (IGF) binding protein complementary deoxyribonucleic acid from human HEPG2 hepatoma cells. Predicted protein sequence suggests an IGF binding domain different from those of the IGF-I and IGF-II receptors. Mol. Endocrinol. 2:404-411.

20. Baxter, R. C., and J. L. Martin. 1986. Radioimmunoassay of growth hormone-dependent insulinlike growth factor binding protein in human plasma. J. Clin. Invest. 78:1504-1512.

21. Clemmons, D. R., L. E. Underwood, and J. J. Van Wyk. 1981. Hormonal control of immunoreactive somatomedin production by cultured human fibroblasts. J. Clin. Invest. 67:10-19.

22. Gourmelen, M., F. Girard, and M. Binoux. 1982. Serum somatomedin/insulin-like growth factor (IGF) and IGF carrier levels in patients with Cushing's syndrome or receiving glucocorticoid therapy. J. Clin. Endocrinol. Metab. 54:885-892.

23. Clemmons, D. R. 1984. Multiple hormones stimulate the production of somatomedin by cultured human fibroblasts. J. Clin. Endocrinol. Metab. 58:850-856.

24. Leof, E. B., W. Wharton, J. J. Van Wyk, and W. J. Pledger. 1982. Epidermal growth factor (EGF) and somatomedin $C$ regulate G1 progression in competent Balb/c-3T3 cells. Exp. Cell Res. 141:107-115.

25. Suikkari, A-M., V. A. Koivisto, E-M. Rutanen, H. Yki-Jarvinen, S-L. Karonen, and M. Seppala. 1988. Insulin regulates the serum levels of low molecular weight insulin-like growth factor-binding proteins. J. Clin. Endocrinol. Metab. 66:266-272.

26. Wahlstrom, T., and M. Seppala. 1984. Placental protein 12 (PP12) is induced in the endometrium by progesterone. Fertil. Steril. 41:781-784.

27. Zapf, J., K. Bing, H. P. Guler, E. Scheiwil, C. Schmid, and E. R. Froesch. 1988. Long term sc infusion of recombinant insulin-like growth factor I induces specific serum carrier proteins in hypox and diabetic rats and in normal man. Endocrinol. Soc. 70:219. (Abstr.)

28. McCusker, R. H., C. Camacho-Huber, and D. R. Clemmons. 1988. Analysis of the forms of insulin-like growth factor binding proteins secreted by muscle cells. Endocrinol. Soc. 70:218. (Abstr.)

29. Scott, C. D., J. L. Martin, and R. L. Baxter. 1985. Production of insulin-like growth factor $I$ and its binding protein by adult rat hepatocytes in primary culture. Endocrinology. 116:1094-1101.
30. Baxter, R. C., J. L. Martin, M. I. Tyler, and M. E. H. Howden. 1986. Growth hormone-dependent insulin-like growth factor (IGF) binding protein from human plasma differs from other human IGF binding proteins. Biochem. Biophys. Res. Commun. 139:1256-1261.

31. Moses, A. C., A. J. Freinkel, B. B. Knowles, and D. P. Aden. 1983. Demonstration that a human hepatoma cell line produces a specific insulin-like growth factor carrier protein. J. Clin. Endocrinol. Metab. 56:1003-1008.

32. Hardouin, S., P. Hossenlopp, B. Segovia, D. Seurin, G. Portolan, C. Lassarre, and M. Binoux. 1987. Heterogeneity of insulin-like growth factor binding proteins and relationships between structure and affinity. 1. Circulating forms in man. Eur. J. Biochem. 170:121-132.

33. Hossenlopp, P., D. Seurin, B. Segovia-Quinson, and M. Binoux. 1986. Identification of an insulin-like growth factor binding protein in human cerebrospinal fluid with a selective affinity for IGF-II. FEBS (Fed. Eur. Biochem. Soc.) Lett. 208:439-444.

34. Hossenlopp, P., D. Seurin, B. Segovia, G. Portolan, and M. Binoux. 1987. Heterogeneity of insulin-like growth factor binding proteins and relationships between structure and function. 2. forms released by human and rat liver in culture. Eur. J. Biochem. 170:133142.

35. Baxter, R. C., J. L. Martin, and M. H. Wood. 1987. Two immunoreactive binding proteins for insulin-like growth factors in human amniotic fluid: relationship to fetal maturity. J. Clin. Endocrinol. Metab. 65:423-431.

36. Rutanen, E.-M., T. Karkkainen, C. Lundquist, F. Pekonen, O. Ritvos, P. Tanner, M. Welin, and T. Weber. 1988. Monoclonal antibodies to the $27-34 \mathrm{~K}$ insulin-like growth factor binding protein. Biochem. Biophys. Res. Commun. 152:208-215.

37. Drop, S. L. S., G. Valiquette, H. J. Guyda, M. T. Corval, and B. I. Posner. 1979. Partial purification and characterization of a binding protein for insulin-like activity in human amniotic fluid: A possible inhibitor of insulin-like activity. Acta Endocrinol. 90:505-518.

38. Meuli, C., J. Zapf, and E. R. Froesch. 1978. NSILA-carrier protein abolishes the action of nonsuppressible insulin-like activity on perfused rat heart. Diabetologia. 14:255-259.

39. Zapf, J., E. Schoenle, G. Jagars, I. Sand, J. Grunwald, and E. R. Froesch. 1979. Inhibition of the action of nonsuppressible insulin-like activity on isolated rat fat cells by binding to its carrier protein. J. Clin. Invest. 63:1077-1084.

40. Ballard, F. J., G. L. Francis, M. Ross, C. J. Bagley, B. May, and J. Wallace. 1987. Natural and synthetic forms of insulin-like growth factor I (IGF-I) and the potent derivative, destripeptide IGF-I: Biological activities and receptor binding. Biochem. Biophys. Res. Commun. 149:398-404.

41. DeLeon, D. D., B. Bakker, D. M. Wilson, R. L. Hintz, and R. G. Rosenfeld. 1988. Demonstration of insulin-like growth factor receptors and binding protein in human breast cancer cell lines. Biochem. Biophys. Res. Commun. 152:398-405.

42. Sturm, M. A., C. A. Conover, H. Pham, and R. G. Rosenfeld. 1988. Insulin-like growth factor receptors and binding protein in rat neuroblastoma cells. Endocrinology. In press.

43. Bachrach, L. K., M. C. Eggo, R. L. Hintz, and G. N. Burrow. 1988. Insulin-like growth factors in sheep thyroid cells. Action, receptors and production. Biochem. Biophys. Res. Commun. 154:861-867.

44. Nissley, S. P., P. A. Short, M. M. Rechler, J. M. Podskalny, and H. G. Coon. 1977. Proliferation of Buffalo rat liver cells in serum-free medium does not depend upon multiplication stimulation activity. Cell. 11:441-446. 